\title{
International Nuclear Waste Management and Its Compliance in Indian Nuclear Power Plants
}

\author{
Ashank Yadav ${ }^{1}$, Sahej Athwal ${ }^{2}$ \\ ${ }^{1,2}$ GD Goenka University, Gurgaon, India.
}

\begin{abstract}
The purpose of the study is to understand importance of responsible nuclear waste management and the laws necessary for its implementation. The study is focused on understanding of how uranium evolved as an important source for power generation as well as prerequisites of safe use of radioactive substances.Study additionally concentrates on the Indian scenario of Statuary laws essential for disposing the nuclear waste responsibly and genuinity of the environmental clearances granted to national power plants under EIA notification. The research concludes with recommendations to amend policy implementation of environment ministry.
\end{abstract}

Keywords: nuclear waste, uranium, radioactive, EIA notification.

\section{Introduction}

Uranium was discovered in 1789, radioactivity was discovered thereafter in 1896 by Marie Curie. All of this lead to the discovery of fission and chain reaction in 1932. By 1939 when the second world was waged labs all over the world started trying to harness the power of fission, success came to Bhor, discovering Uranium 235 isotope, now the power of fission could be harnessed successfully. By 1939, Francis perrin introduced the concept of first atomic bomb. Perrin's group in paris published a report ststing that absorption of constituants of chain reaction could be used to generate power. A gathering of researchers known as the MAUD Committee was set up in Britain, the MAUD Committee then submitted rundown reports in July 1941. One was on 'Utilization of Uranium for a Bomb' and the other was on 'Utilization of Uranium as a Source of Power'. The primary report inferred that a bomb was attainable and that one containing somewhere in the range of $12 \mathrm{~kg}$ of dynamic material would be identical to 1,800 tons of TNT and would discharge expansive amounts of radioactive substances which would make places close to the blast site hazardous to people for a long stretch. The second MAUD Report inferred that the controlled splitting of uranium could be utilized to give vitality as warmth for use in machines, and also giving extensive amounts of radioisotopes which could be utilized as substitutes for radium. The two reports prompted a complete revamping of work on the bomb and the 'boiler'.' Little accentuation was given to the bomb idea until 7 December 1941, when the Japanese attacked Pearl Harbor and the Americans entered the war straightforwardly. The enormous assets of the USA were then connected without reservation to creating nuclear bombs. ${ }^{2}$ The primary nuclear gadget tried effectively at Alamagordo in New Mexico on 16 July 1945. It utilized plutonium made as a part of an atomic heap. The groups did not consider that it was important to test a more straightforward U-235 gadget. The primary nuclear bomb, which contained U-235, was dropped on Hiroshima on 6 August 1945. ${ }^{3}$ The principal atomic reactor to deliver power was the little Experimental Breeder reactor (EBR-1) outlined and worked by Argonne National Laboratory and sited in Idaho, USA. The reactor began up in December 1951. The Mark 1 model maritime reactor began up in March 1953 in Idaho, and the primary atomic controlled submarine, USS Nautilus, was dispatched in 1954. In 1959 both USA and USSR propelled their first atomic controlled surface vessels.

In the USA, Westinghouse outlined the principal business PWR of $250 \mathrm{MWe}$, Yankee Rowe, which began up in 1960 and worked to 1992. Then the boiling water reactor (BWR) was produced by the Argonne National Laboratory, and the first, Dresden-1 of $250 \mathrm{MWe}$, composed by General Electric, was begun up prior in 1960. A model BWR, Vallecitos, kept running from 1957 to 1963. In Kazakhstan the world's first business model quick neutron reactor (the BN-350) began up in 1972, delivering $120 \mathrm{MW}$ of power and warmth to desalinate Caspian seawater. In the USA, UK, France and Russia various test quick neutron reactors created power from 1959, the remainder of these shutting in 2009. This exited Russia's BN-600 as the main business reactor. the late 1990s the first of the third-era reactors was authorized - Kashiwazaki-Kariwa 6 - a 1350 MWe Advanced BWR, in Japan. This was an indication of the recuperation to come. The historical backdrop of atomic power in this way begins with science in Europe, blooms in UK and USA with the last's innovative may, grieves for a couple of decades, then has another development spurt in east Asia. 


\section{Significance Of Responsible Disposal Laws For Nuclear Wastes}

Any activity related to the nuclear fuel cycle, that produces or uses radioactive materials generates radioactive waste. The management of radiation emitting radioactive material is a matter of concern and is what sets nuclear wastes apart. Public acceptance of nuclear energy largely depends on the public assurance for safe management of radioactive wastes. Not all nuclear wastes are particularly hazardous or hard to manage as compared to other toxic industrial wastes. It is also a time of heightened global concern about nuclear energy after the earthquake and the fear of the radioactive releases from the affected damaged reactors in Japan. In accordance with international guidelines, a coherent comprehensive and consistent set of principles and standards are being practiced all over the world for waste management system ${ }^{4}$.

Radioactive wastes are generated during various operations of the nuclear fuel cycle. Mining, nuclear power generation, and various processes in industry, defense, medicine and scientific research produce byproducts that include radioactive wastes. Radioactive waste can be in gas, liquid or solid form, and its level of radioactivity can vary. The waste can remain radioactive for a few hours or several months or even hundreds of thousands of years. Depending on the level and nature of radioactivity, radioactive wastes can be classified as exempt waste, Low \& Intermediate level waste and High Level Waste ${ }^{5}$.

In India there is no legislation to protect the disposal of the nuclear waste, unlike other nations where there is a separately drafted Nuclear Waste Disposal Act ${ }^{6}$. An Act to provide for the development of repositories for the disposal of high-level radioactive waste and spent nuclear fuel, to establish a program of research, development, and demonstration regarding the disposal of high-level radioactive waste and spent nuclear fuel, and for other purposes $^{7}$. Lack of proper institutions which teach nuclear science and waste disposal, which clearly shows the insufficiency of India to undertake nuclear waste disposal methods.

The kind of waste transmitted is High-level waste (HLW) emerges from the "smoldering" of uranium fuel in an atomic reactor. HLW contains the parting items and transuranic components produced in the reactor center. It is exceedingly radioactive and hot because of rot warmth, so requires cooling and protecting. It has warm power above around $2 \mathrm{~kW} / \mathrm{m} 3$ and can be considered as the "powder" from "smoldering" uranium. HLW represents more than $95 \%$ of the aggregate radioactivity delivered during the time spent power era. ${ }^{8} \mathrm{HLW}$ has both seemingly perpetual and fleeting segments, contingent upon the timeframe it will take for the radioactivity of specific radionuclides to lessening to levels that are viewed as no more perilous for individuals and the encompassing environment. On the off chance that by and large brief splitting items can be isolated from seemingly perpetual actinides, this qualification gets to be vital in administration and transfer of HLW. HLW is a noteworthy center of consideration with respect to atomic force, and the business has recommended that any choice for the administration of utilized atomic fuel is practical. ${ }^{9}$

\section{Statuary Laws Essential To Dispose The Nuclear Waste Responsibly In India}

Pretty much according to capita utilization of power is identified with the way of life in a nation, the power era by atomic means can be viewed as a base measure of radioactive waste that is produced by a nation and henceforth the related size of radioactive waste administration. On the size of atomic offer of power era, India positions fourth from the base in around 30 nations. ${ }^{10}$ As of the year 2000, India's offer of atomic power era in the aggregate power era in the nation was $2.65 \%$ contrasted with $75 \%, 47 \%, 42.24 \%, 34.65 \%, 31.21 \%$, $28.87 \%, 19.80 \%, 14.41 \%$ and $12.44 \%$ of France, Sweden, the Republic of Korea, Japan, Germany, UK, USA, Russia and Canada, individually. The reactors in operation produce in net Gigawatts (one billion (109) watts) (E) in the last nations almost 63, 9,13, 44, 21, 13, 97, 20 and 10, separately; India's reactors in operation yield 1.9 on this scale (both information are according to IAEA Report of 2000). ${ }^{11}$ Henceforth the greatness of radioactive waste administration in India could be miniscule contrasted with that in different nations, particularly when one considers the atomic munititions stockpile as of now in stockpile in the atomic weapons nations. As more power reactors come onstream and as weaponization takes more profound courses the requirements of radioactive waste administration increment and in this connection the experience of different nations would give helpful lessons ${ }^{12}$.

Radioactive waste administration has been a necessary part of the whole atomic fuel cycle in India. Low-level radioactive waste and middle of the road level waste emerge from operations of reactors and fuel reprocessing offices. The low-level radioactive waste fluid is held as muck after concoction treatment, bringing about purification variables running from 10 to 1000. Strong radioactive waste is compacted, safeguarded or burned relying on the way of the waste. Sun based evapora-tion of fluid waste, reverse osmosis and immobilization utilizing concrete framework are received relying upon the type of waste. ${ }^{13}$ Underground built trenches in close surface transfer offices are used for transfer of strong waste; these transfer locales are under persistent reconnaissance and checking. High effectiveness particulate air (HEPA) channels are utilized to minimize air- 
International Nuclear Waste Management and Its Compliance in Indian Nuclear Power Plants

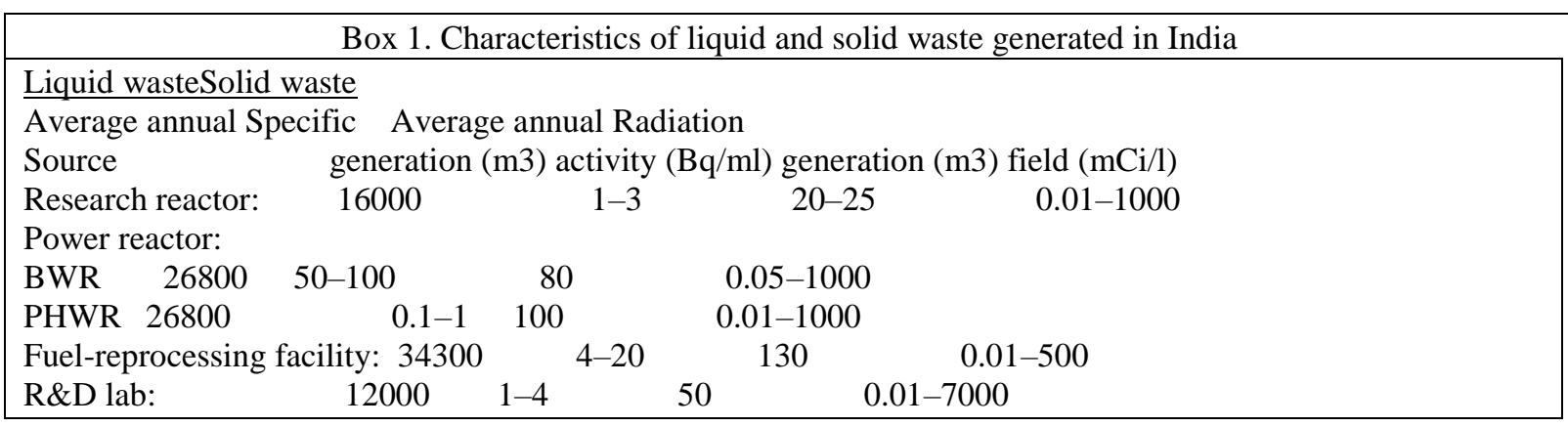

borne radioactivity ${ }^{14}$. In the course of recent decades' radioactive waste administration offices have been set up at Trombay, Tarapore, Rawatbhata, Kalpakkam, Narora, Kakrapara, Hyderabad and Jaduguda, alongside the development of atomic power and fuel-reprocessing plants. Multiple-barrier methodology is followed in taking care of strong waste. Box 1 demonstrates the qualities of fluid and strong waste created in India. After the appointing of the quick raiser test reactor at Kalpakkam, one is required to reprocess the blazed carbide fuel from this reactor. As the wreck of this fuel is prone to be of the request of $100 \mathrm{MWD} / \mathrm{kg}$, about a request of size more than that of warm reactors and because of short cooling-time before reprocessing, particular action to be taken care of will be incredibly upgraded. The utilization of carbide fuel would bring about new types of chemicals in the reprocessing cycle. These give new difficulties to quick reactor fuel reprocessing. ${ }^{15}$

Along these lines with keeping in perspective of this information, it is basically required by India to build up an Act to accommodate the improvement of stores for the transfer of abnormal state radioactive waste and spent atomic fuel, to set up a system of examination, advancement, and exhibition in regards to the transfer of abnormal state radioactive waste and spent atomic fuel, and for different purposes. ${ }^{16}$

\section{Genuinity Of The Environmental Clearances Granted To National Power Plants Under Eia Notification}

India is being highlighted repeatedly for non-compliance of environment safety standards which creates trouble for establishment of any new nuclear power plant in the country. Even in the case of $G$. Sundarrajan vs. Union of India (2013) 6 SCC $620^{17}$, construction of Koodankulam Nuclear Power Plant next to Bay of Bengal Sea in the South-Eastern tip of India, in the State of Tamil Nadu was opposed by the public, although Supreme Court of India dismissed the petition stating that power plant needs to strictly dispose the nuclear waste in a responsible manner ${ }^{18}$. On May 6, 2013, a two-member bench of Supreme Court of India (Justice K.S. Radhakrishnan \& Justice Dipak Misra) dismissed the appeal against Madras High Court judgment and gave green signal with some mild conditions for commissioning the controversial Koodankulam Nuclear Power Plant next to Bay of Bengal Sea in the South-Eastern tip of India, in the State of Tamil Nadu. The appeal was against the refusal of Madras High Court to stay the completion and commissioning work on the first unit of 1000 MWe Russian VVER type nuclear reactor. There are two units of $1000 \mathrm{MWe}$ each under construction at Koodankulam.

Special focus has been put over the recent controversy arisen due to construction of nuclear power plant of the Gorakhpur Nuclear Power Plant, (GHAVP) is a proposed nuclear power plant to be built in the Gorakhpur Village of Fatehabad district of Haryana ${ }^{19}$. The public hearing for environmental clearance was done without obtaining EIA and even the locals had stated that the public hearing was fake and not a substantial one $^{20}$.Haryana State Pollution Control Board endeavored to hold a fake open hearing for the proposed 2800 MW atomic force plant at Gorakhpur town in Fatehabad region by focal government's Nuclear Power Corporation of India Limited (NPCIL) without the Environment Impact Assessment (EIA) report on 17 July, 2012 at Sahid-eAzam Bhagat Singh Stadium in Gorakhpur, Fatehabad, Haryana. Villagers' intense challenge against the plant in the setting of artificial calamity of Fukushima constrained the authorities to cluster together and leave the venue suddenly. The plot between the organization and the NPCIL was very show.

The villagers underlined that such plants ought not to be set up. An aggregate 1503.5 sections of land of farming area is required for the venture. The villagers turned up in tremendous numbers to criticize the atomic force plant in the midst of enormous police nearness. The furious dissent of Haryana villagers a day after greatest rally in Tokyo after synthetic calamity of Fukushima requested a conclusion to atomic force connotes the solidarity of the battle. An extensive candlelight vigil encompassing the Japanese Parliament is planned for July 29. In Fatehabad, a major system is moved toward August 17, 2012 against the Gorakhpur atomic force venture. An examination of the Indian experience' by M.V. Ramana wherein he has rightly contended that "the EIA process as to atomic tasks in India is of questionable quality." The three levels of irreconcilable circumstance that has been recognized in the EIA process for atomic offices are important for the EIA report of the proposed nuclear force plant in Fatehabad. To begin with, the EIA is set up by advisors who are held to work 
onbehalf of, and by suggestion act in light of a legitimate concern for, their customer the atomic association proposing the task. Second, the association that has been tasked with setting up the EIA to bolster its proposition for an undertaking, is the same association that will benefit from the venture. The third irreconcilable circumstance is that the administrative office Atomic Energy Regulatory Authority is itself controlled by the atomic force promoters, the Atomic Energy Commission which is under the immediate charge of the Prime Minister.

The EIA report uncovers that the water necessity for the undertaking will be met from Fatehabad Branch of Bhakra Canal. Dissimilar to ocean as a wellspring of water on account of Fukushima, in Fatehabad, waterway water is the main hotspot for water. A point by point evaluate of the voluminous EIA report is under arrangement. Inside minutes of the takeoff of the authorities from the venue of the stage oversaw and fake open hearing because of gigantic resistance from a huge number of villagers who are against the setting of the dangerous plant in their rich horticultural area. Powers delineated the fake way of general society listening to prepare as they forgot without perusing the minutes of the procedures and looking for assent of the villagers who were there as is compulsory under Environment Impact Assessment Notification, 2006. It is vital that the separation in the middle of Fukushima and Tokyo is 238 kilometers notwithstanding this after the atomic fiasco on 11 March 2011, driving Tokyo populace to empty. The separation in the middle of Delhi and Fathehabad where the atomic force undertaking is proposed is $210 \mathrm{~km}$. It's about time that inhabitants of Delhi drew in with the inescapable atomic radiation dangers from the proposed nuclear force plant and arranged for crisis clearing if the Fatehabad office comes up. The EIA report has been set up by Ranchi based MECON Limited, some time ago known as (Metallurgical and Engineering Consultants (India) Limited), an open area undertaking under the Union Ministry of Steel. People groups' development has for quite some time been requesting that Mecon ought to be boycotted for consistently delivering low quality and misdirecting reports for uranium mines. The EIA report arranged by Mecon which was released one day in front of the absurd open hearing is appended other than the Executive Summary.

\section{Recommendations To Amend Policy Implementation Of Environment Ministry}

With the need of specific recommendation, the study has come up with some of the recommendations to amend policy implementation in regard to nuclear waste safe disposal:

\section{Securely Managing Used Fuel}

Building up a transfer area for the long haul administration of utilized uranium fuel from atomic force plants. Have a reasonable project for the administration of utilized atomic fuel from business atomic vitality offices and abnormal state radioactive waste from the administration's guard and research exercises.

\section{Incorporated Used Fuel Management}

Until the government puts set up a system to discard these materials, about all business utilized fuel is put away securely and safely at the reactor destinations in steel-lined solid pools loaded with water, or in hermetically sealed steel or cement and-steel holders. This brief stockpiling is yet one segment of a coordinated utilized fuel administration framework. Different features incorporate reusing, transportation and last geologic transfer.

\section{Utilized Nuclear Fuel Storage}

Utilized atomic fuel comprises of little uranium pellets stacked inside combination fuel poles. All the utilized atomic fuel created by the atomic vitality industry in about 50 years if stacked end to end would cover a territory the measure of a football field to a profundity of under 10 yards. Improvement of a merged area for transitory stockpiling of utilized atomic fuel as a part of a ready host group and state, while considerable advancement is made toward building up the geologic archive.

\section{Transportation}

Obligation to transport utilized atomic fuel from atomic vitality area destinations to provisional storerooms and to a vault. Transport should be directed by rail and street, utilizing monstrous, fixed compartments that meet strict wellbeing and security prerequisites.

\section{Transfer}

Whether atomic fuel is utilized just once or reused for resulting use, transfer of abnormal state radioactive repercussions in a perpetual geologic vault is vital. Underground transfer in an uncommonly planned office is a crucial component of a supportable, coordinated utilized atomic fuel administration program.

\section{Reusing Used Nuclear Fuel}

The business underpins exploration, advancement and showing of enhanced or propelled fuel cycle advances, for example, reusing, consequently conceivably lessening the volume, warmth and poisonous quality of repercussions put in the vault. A geologic vault will be required for all fuel cycles.

\section{Low-Level Radioactive Waste}

Low-level waste is a result of the valuable employments of an extensive variety of radioactive materials. These incorporate power era, therapeutic conclusion and treatment, and different other medicinal procedures. 


\section{Conclusion}

The issues connected with radioactive waste administration on a long haul are significant ones that mankind has not possessed the capacity to grapple with as such. The issue of radioactive waste administration has been contrasted with a Gordian knot. The Gordian knot ought not to be simply cut through snappy and deftly. As American Ambassador Rich III put it, 'The snags can't be over soon or overlooked. We should join the Gordian knot deliberately and meticulously, utilizing the majority of our assets and popularity based establishments carefully and well'. It is almost 45 years since the IAEA was established. Over these years the Agency has pondered on different issues that stand up to radioactive waste administration and has been giving rules and gatherings to specialized and non-specialized civil arguments and discourses. As time cruises by, new issues crop up, which should be examined. One sample is the way does one 'arrangement for retirement of atomic offices', once in a while alluded to as 'decommissioning of offices'. Also changes in ideas of long haul issues on wellbeing and security should be tended to 'dosage and danger for a remote time later on are not trustworthy, since propensities for human populaces are difficult to be anticipated'. All choices have not been analyzed in totality. 'The benefit of learning by all-encompassing investigations of supposed normal analogs is getting acknowledged. These are characteristic frameworks, or archeological antiquities that display a portion of the key elements that storehouse investigators need to get it. By concentrate how these frameworks have developed over land time scales, one can pick up bits of knowledge into future store advancement. The issues won't be comprehended by tossing boundless cash at them. Some procedures take as much time as is needed to fructify.

\section{References}

[1] Retrieved 11 Mar. 2017 fromHardy, C. (1999). Atomic Rise and Fall: The Australian Atomic Energy Commission, 1953-1987. Glen Haven Publishing.

[2] Retrieved 14 Mar. 2017 from http://dtic.mil/doctrine/doctrine/history/chairmanshipjcs1949_2016.pdf.

[3] Retrieved 22 Mar. 2017 from Spencer, W. (1988). Nuclear Fear: A History of Images, Harvard University Press.

[4] Vandenbosch, R., \& Vandenbosch, S. E. (2007). Nuclear waste stalemate: Political and scientific controversies. University of Utah Press.

[5] Abbotts, J. (1979). Radioactive waste: a technical solution?. Bulletin of the Atomic Scientists, 35(8), 12-18. Retrieved from: http://www.tandfonline.com/doi/abs/10.1080/00963402.1979.11458649?journalCode=rbul20, accessed on 11.04.2017

[6] Retrieved 14 Mar. 2017 fromhttps://energy.gov/sites/prod/files/edg/media/nwpa_2004.pdf

[7] Retrieved 15 Mar. 2017 fromhttps://inis.iaea.org/search/search.aspx?orig_q=RN:37004120.

[8] Retrieved 22 Mar. 2017 fromhttp://www-pub.iaea.org/MTCD/publications/PDF/TRS446_web.pdf.

[9] Retrieved 15 Mar. 2017 fromBulletin of the Atomic Scientists Feb 1963, https://books.google.co.in/books?id=ewcAAAAAMBAJ\&pg=PA26\&lpg=PA26\&dq=On+the+size+of+atomic+offer+of+power+er a,+India+positions+fourth+from+the+base+in+around+30+nations\&source=bl\&ots=TR_FK_WONd\&sig=VBKw7rbPhR0VigW9 Oki3MQ5OpyM\&hl=en\&sa=X\&ved=0ahUKEwjn0KmCvZ_TAhVCsI8KHZWzCUQQ6AEISTAH\#v=onepage\&q\&f=false .

[10] Retrieved 22 Mar. 2017 fromhttp://tejas.serc.iisc.ernet.in/currsci/dec252001/1534.pdf

[11] Retrieved 14 Mar. 2017 from http://www.iaea.org/inis/collection/NCLCollectionStore/_Public/27/057/27057469.pdf.

[12] Vandenbosch, R., \& Vandenbosch, S. E. (2007). Nuclear waste stalemate: Political and scientific controversies. University of Utah Press.

[13] Erickson, J. D., Chapman, D., \& Johnny, R. E. (1994). Monitored retrievable storage of spent nuclear fuel in Indian Country: Liability, sovereignty, and socioeconomics. American Indian Law Review, 19(1), 73-103. Retrieved from: http://www.uvm.edu/ jdericks/pubs/AILR.pdf, accessed on 03.03.2017

[14] Hinkle, S. (2015). Radioactive Waste Disposal: A Policy Change on the Horizon. Retrieved from: http://www.wiseintern.org/journal/2015/documents/Radioactive_Waste_DisposalSHinkle.pdf, accessed on 05.04.2017

[15] Abbotts, J. (1979). Radioactive waste: a technical solution?. Bulletin of the Atomic Scientists, 35(8), 12-18. Retrieved from: http://www.tandfonline.com/doi/abs/10.1080/00963402.1979.11458649?journalCode=rbul20, accessed on 11.04.2017

[16] G. Sundarrajan vs. Union of India (2013) 6 SCC $620 . \quad$ Retrieved from: https://indiankanoon.org/docfragment/193909599/?formInput=G.\%20Sundarrajan\%20vs.\%20Union\%20of\%20India\%20\%282013 $\% 29 \% 206 \% 20$ SCC\%20620, accessed on 22.02.2017.

[17] Retrieved 15 Mar. 2017 fromhttp://www.thehindu.com/news/national/tamil-nadu/kudankulam-nuclear-plant-cleared-withcaveats/article4688502.ece, accessed on 22.02.2017.

[18] http://www.npcil.nic.in/main/Clearances_for_GHAVP_Site.aspx, accessed on 28.02.2017.

[19] http://southasia.oneworld.net/news/indian-nuclear-plant-to-get-clearance-without-making-eia-report-public\#.Vs1SkeFunmR, accessed on 22.03.2017

[20] Shrader-Frechette, K. S. (1988). Values and Hydrogeological Method: How Not to Site the World's Largest Nuclear Dump. Planning for Changing Energy Conditions, J. Byrne and D. Rich (eds.). New Brunswick: Transaction Books, $101-137$.

[21] Hebert, H. J. (2009). Nuclear waste won't be going to Nevada's Yucca Mountain, Obama official says. Chicago Tribune, March 6, 4.

[22] Dharm, D., \& Shrirang, J. (2015). Judicial Contribution to Protect Environment Through Sustainable Development in India: An Overview. International Journal of Legal Research, 1(3). 